\title{
AIR POLLUTION AND POTENTIAL HEALTH RISK IN OSTRAVA REGION - A REVIEW
}

\author{
Vítězslav Jiřík', Ondřej Machaczka², Hana Miturová2, Ivan Tomášek ${ }^{2,3}$, Hana Šlachtová1, Jana Janoutová1, Helena \\ Velická4, Vladimír Janout ${ }^{1}$ \\ 'Department of Epidemiology and Public Health, Faculty of Medicine, University of Ostrava, Ostrava, Czech Republic \\ ${ }^{2}$ Centre of Epidemiological Research, Faculty of Medicine, University of Ostrava, Ostrava, Czech Republic \\ ${ }^{3}$ Institute of Public Health in Ostrava, Ostrava, Czech Republic \\ ${ }^{4}$ National Institute of Public Health, Prague, Czech Republic
}

\section{SUMMARY}

Aim: The aim of this review was to collect all available data about air pollution in Ostrava, which is one of the most polluted area in central Europe and to make a concise assessment of health risks resulting from historical exposures of air pollutants since the beginning of the monitoring, i.e. since 1970 to the present time.

Methods: All available information sources (the Czech Hydrometeorological Institute, the Institute of Public Health in Ostrava or publications) were used. To evaluate the exposures both short-term (hourly and daily) data and long term (yearly) data during 45 years were analysed. For health risk assessment the relationship between exposure and biological effects of pollutants published by the WHO and the US EPA were employed.

Results: During the studied period annual average concentrations of $\mathrm{PM}_{10}$ ranged from 25 to $96 \mu \mathrm{g} / \mathrm{m}^{3} ; \mathrm{PM}_{2.5}$ from 24 to $45 \mu \mathrm{\mu g} / \mathrm{m}^{3} ; \mathrm{SO}_{2}$ from 3.4 to $101.5 \mu \mathrm{g} / \mathrm{m}^{3} ; \mathrm{NO}_{2}$ from 17.76 to $51.17 \mu \mathrm{g} / \mathrm{m}^{3}$; benzene from 0.24 to $9.2 \mu \mathrm{g} / \mathrm{m}^{3}$; benzo[a]pyrene from 2.1 to $14 \mathrm{ng} / \mathrm{m}^{3} ;$ arsenic from 1.2 to 9.5 $\mathrm{ng} / \mathrm{m}^{3}$. Since the turn of the $80 \mathrm{~s}$ and $90 \mathrm{~s}$ of the 20th century trend of air pollutant concentrations has been decreasing until the turn of millennium, when it stopped, and it has been constant until present time. However, presented results demonstrate that the citizens of Ostrava have been exposed to relatively high concentrations of pollutants in comparison to other similar cities. The most significant pollutants contributing to health risks are airborne dust $\left(\mathrm{PM}_{10}, \mathrm{PM}_{2.5}\right)$, benzene and benzo[a]pyrene. The long-term average health risk of $\mathrm{PM}_{10}$ has increased in case of postneonatal infant mortality up to $30 \%$; prevalence of bronchitis in children up to $61 \%$; and incidence of chronic bronchitis in adults up to $89 \%$. The long-term average health risk of $\mathrm{PM}_{2.5}$ increased for all-cause mortality in persons aged 30+ years up to $22 \%$; cardiopulmonary related mortality up to $25 \%$; and lung cancer related mortality up to $39 \%$. The highest carcinogenic risk is observed in benzo[a]pyrene, when the range of individual lifetime carcinogenic risk is up to $1.25^{*} 10^{-3}$. This assessment is valid according to the strict carcinogenic risk by the WHO, while the maximum carcinogenic risk according the US EPA is $7.2^{*} 10^{-5}$.

Conclusions: A significant reduction of the pollutants' concentrations in Ostrava in the nineties of the last century does not mean a required improvement of outdoor air quality to the desired level. Persisting episodes with a very strong short-term increase of the concentration of $\mathrm{PM}_{10}$ and $\mathrm{PM}_{2.5}$ as well as long-term load of these substances on the population is very high. Health risks from such burdens are likely to lead to a higher mortality and morbidity especially from specific diseases.

Key words: air pollutants, particulate matter, short-term and long-term exposure, specific mortality and morbidity, carcinogenic risk

Address for correspondence: V. Jirík, Department of Epidemiology and Public Health, Faculty of Medicine, University of Ostrava, Syllabova 19, 70300 Ostrava. E-mail: Vitezslav.Jirik@osu.cz

http://dx.doi.org/10.21101/cejph.a4533

\section{INTRODUCTION}

The city of Ostrava is located in the Czech Republic on the border of historical regions Moravia and Silesia in the south-western part of the Upper Silesian metropolitan area (shared today with Poland), with population of about 5.3 million inhabitants. Ostrava is the county seat of the Moravian-Silesian Region of the Czech Republic that counts 1.2 million inhabitants to the date of 30th Sept 2014 and includes so-called Ostrava agglomeration, which is defined by the cadastral area of the cities Ostrava, Bohumín, Doubrava, Havířov, Karviná, Orlová, Petřvald, and Rychvald. The total area of Ostrava includes $248.1 \mathrm{~km}^{2}$ and a population of 496,217 inhabitants to the date of 1 st Jan 2014. The city of
Ostrava itself has an area of $214.23 \mathrm{~km}^{2}$ (86\% of the Ostrava agglomeration) and 302,969 inhabitants $(59 \%$ of the Ostrava agglomeration) to the date of 1 st Jan 2015.

The beginning of the exact measurement of air pollutant concentrations in Ostrava is dated to the first half of the seventies of the 20th century. The measurements were performed by more institutions: the Czech Hydrometeorological Institute (CHMI), the Regional and the District health authorities (up to 2003), the Institute of Public Health in Ostrava (since 2003), and to a lesser extent some other institutions. The data before 1970 are not available. Currently Ostrava agglomeration is considered one of the most polluted area in the European Union in terms of the most serious air pollutants, i.e. airborne dust (1). 


\section{MATERIALS AND METHODS}

A more systematic measurement of air pollution concentrations in the area of Ostrava started in 1970. Several measurement stations were operating (Table 1 ), whereby only $\mathrm{SO}_{2}$ concentrations were measured. Since 1972 concentrations of dust-fall have been measured, i.e. dust particles with an aerodynamic diameter $>100$ $\mu \mathrm{m}$ and airborne dust, then so called total fraction, i.e. particles with an aerodynamic diameter $<100$ microns.

At that time conventions used today have not yet been adopted i.e. according to which sampling equipment is constructed and specific fractions of airborne dust are sampled, i.e. total fraction (newly inhalable fraction, often referred to as total suspended particles-TSP), thoracic fraction, respirable fraction, or fraction $\mathrm{PM}_{10}$ and $\mathrm{PM}_{2.5}$.

Except those mentioned, other important air pollutions were systematically measured in Ostrava region: sulphur dioxide $\left(\mathrm{SO}_{2}\right)$, total nitrogen oxides $\left(\mathrm{NO}_{\mathrm{x}}\right)$, ozone and carbon monoxide, airborne dust compounds (metals and volatile organic), carcinogenic benzene and polycyclic aromatic hydrocarbons (PAH - including benzo[a]pyrene).

The main sources of air pollution in the city of Ostrava are industry and power engineering, local heating and automobile traffic.

Already in 1763 deposits of a high quality coal were discovered in the present territory of the city of Ostrava, which resulted in the origin of heavy industry (establishment of ironworks) and a progressive development of the city of Ostrava. This is an area where a long-term politically motivated process put preferences on heavy industry. Other industrial sectors, agricultural production and largely also tertiary sphere fulfil only a complementary function. Today industries such as metallurgical, chemical, heavy engineering, power production and construction predominate. The gradual decrease of production and associated reduction of emissions at the turn of the 80 s and 90 s of the 20th century followed cessation of the coal mining in 1994, end of metallurgical production in Vítkovice in 1998 and restructuring of industry. The largest share of heavy industry is currently metallurgy, steel production, chemical industry and coke-ovens. Major emitters of all pollutants of interest in Ostrava are particularly stationary and stationary combustion sources, which list can be found on the websites of the CHMI (2). Historical development of emissions from stationary sources is described in the paper (3) and since 1980, when total emissions had amounted to 65,301 tons/year these values have decreased to 929 tons/year in 2012 .

Pollution caused by traffic is significant in Ostrava, especially around busy roads, in major intersections and in the city centre. For example, the highest $\mathrm{NO}_{\mathrm{x}}$ emission yield has been for a long time detected in the street Rudná, specifically in the section Frýdek-Místek (5,969 tons/km/year), where 28,536 vehicles pass daily. The second largest pollution load was calculated for the year 2012 in the street Rudná, specifically in the section between exits and ramps to the street Výškovická (5,335 tons/km/year) and consequently in the section between the street Výškovická and Plzeňská (5,250 tons/km/year) where 32,345 vehicles pass a day (annual average) (4). According to the Census of people, houses and flats in 2011 conducted by the Czech Statistical Office almost 56,000 household were heated by solid fuels (coal, coke, coal briquettes or wood - excluding heating outside the house) which is about $12 \%$ of inhabited dwellings in the Ostrava city. In addition, less than 5,800 in use, i.e. over $4 \%$ of inhabited dwellings were counted in this area. Concurrently the same data showed that in the most polluted part of the Ostrava-Karviná agglomeration was one of the highest densities of local heating of the MoravianSilesian Region and also in the Czech Republic (5). Areas with a higher proportion of emissions from individual heating (the most important is TSP) are located in the outer and also inner parts of Ostrava, especially in urban districts Vítkovice or Slezská

Table 1. Zones, municipal districts and measurement stations in Ostrava

\begin{tabular}{|c|c|c|c|}
\hline \multirow{2}{*}{ Zone (population number*) } & \multirow{2}{*}{ Monitored city part } & \multicolumn{2}{|c|}{ Year } \\
\hline & & Start of monitoring & End of monitoring \\
\hline \multirow{3}{*}{$\begin{array}{l}\text { OVA } 1 \\
(86,449)\end{array}$} & Polanka & 2002 & 2003 \\
\hline & Poruba & 1970 & continue \\
\hline & Svinov & 1988 & 1993 \\
\hline \multirow{6}{*}{$\begin{array}{l}\text { OVA } 2 \\
(133,994)\end{array}$} & Bělský les & 1970 & 1975 \\
\hline & Fifejdy & 1985 & continue \\
\hline & Hrabůvka & 1988 & 1993 \\
\hline & Mariánské Hory & 2004 & continue \\
\hline & Stará Bělá & 1970 & 1976 \\
\hline & Zábřeh & 1970 & continue \\
\hline \multirow{6}{*}{$\begin{array}{l}\text { OVA } 3 \\
(82,526)\end{array}$} & Petřkovice & 1970 & 1991 \\
\hline & Kunčice & 1985 & 1997 \\
\hline & Moravská Ostrava & 1970 & 1986 \\
\hline & Prívoz & 1999 & continue \\
\hline & Radvanice & 1970 & continue \\
\hline & Slezská Ostrava & 1971 & 2003 \\
\hline
\end{tabular}

*Number of inhabitants to date 1st January 2015 
Ostrava, Michalkovice, Ostrava-Jih, Stará and Nová Bělá, and Polanka nad Odrou. To the maximum emissions-abundant sites, however, belong to basic administrative units in the Cadastre of Hrušov located in the municipal district Slezská Ostrava with the annual TSP emission flow of $6.9 \mathrm{~g} / \mathrm{m}^{2}$ and in the Cadastre of the municipal district Mariánské Hory and Hulvaky (6).

Spatial and temporal distribution of air pollutant concentration in Ostrava region is significantly influenced by geographic and meteorological conditions. The average altitude in the City reaches 227 meters above sea level with the highest point at 336 meters above sea level (municipal district Krásné pole) and the lowest point at 193 meters above sea level (municipal district Slezská Ostrava) (7). The orientation profile of the Upper Silesian Basin from Jeseníky to Beskydy is shown in Figure 1 and it is one of the leading causes of air pollutants accumulation in this region and thus frequent occurrence of their relatively high concentrations.

Except of specific geographical conditions significant role in air pollution is also played by meteorological conditions, especially temperature, wind direction and velocity (Fig. 2).

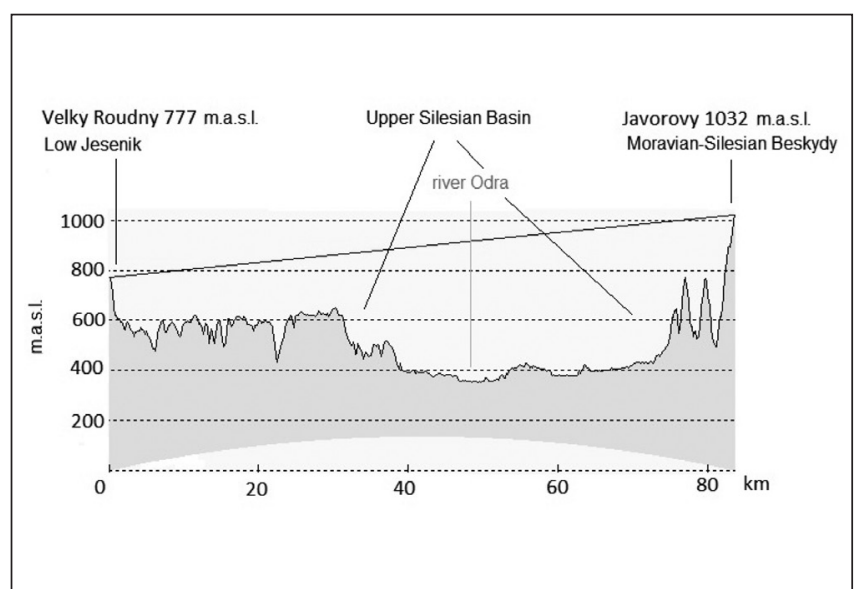

Fig. 1. Cross-section of the Upper Silesian Basin in the junction between Velký Roudný in the Low Jeseník and Javorovy in the Moravian-Silesian Beskydy mountains.
The annual average temperature is $8.6^{\circ} \mathrm{C}$. The annual average precipitation reaches $568.3 \mathrm{~mm}$. Due to the prevailing wind direction (Fig. 2), the location of the major sources of pollution, monitoring results and historical experience with spatial placement of monitoring stations, the city of Ostrava can be roughly divided into 3 zones by increasing average concentrations of pollutants, i.e. to the zone 1 (OVA 1) - low polluted area, the zone 2 (OVA 2) - middle polluted area and the zone 3 (OVA 3) - the most polluted area (Table 1).

In Table 1 in addition to some detailed information about the division of the city of Ostrava and measuring stations location, also the relevant population numbers are shown.

\section{RESULTS}

In the Figure 3 and Table 2 historical trend of airborne dust concentrations in Ostrava expressed as the concentration of $\mathrm{PM}_{10}$ according to internationally accepted conventions is presented. In the period from 1972 to 1996 , the measured concentrations of total dust are converted to $\mathrm{PM}_{10}$ according to experimentally identified proportion of $\mathrm{PM}_{10} / \mathrm{TSP}=0.608$ as measured in the mid-nineties (9). According to the WHO, the $\mathrm{PM}_{10}$ proportion out of the total amount of total suspended particles (TSP) in the air achieves around $80 \%(10)$. In contrast, e.g. Bogo et al. (11) state that in average $60 \%$ of TSP consists of $\mathrm{PM}_{10}$ particles that is comparable to the value seen directly in Ostrava. Since the year 1997 the measurement of $\mathrm{PM}_{10}$ has been included in a regular monitoring of air quality.

The results of $\mathrm{PM}_{2.5}$ concentrations monitoring are introduced in the Figure 4 and Table 3. A systematic measurement of $\mathrm{PM}_{2.5}$ was started up as late as in 2004. The WHO recommendations (12) were specified based on the estimate of the average ratio of $\mathrm{PM}_{2.5}$ in $\mathrm{PM}_{10}$ between $0.5-0.8$ in developed country urban areas. The average annual ratio of $\mathrm{PM}_{2.5} / \mathrm{PM}_{10}$ in 2012 calculated from simultaneously measured values at 35 stations ranged from 0.46 (in Prague) to 0.87 (Liberec) with a mean value of 0.76 . The $\mathrm{PM}_{25} / \mathrm{PM}_{10}$ ratio found out at the municipal stations in Ostrava in the year 2013 was 0.74 at the station TOPRA and 0.78 at the

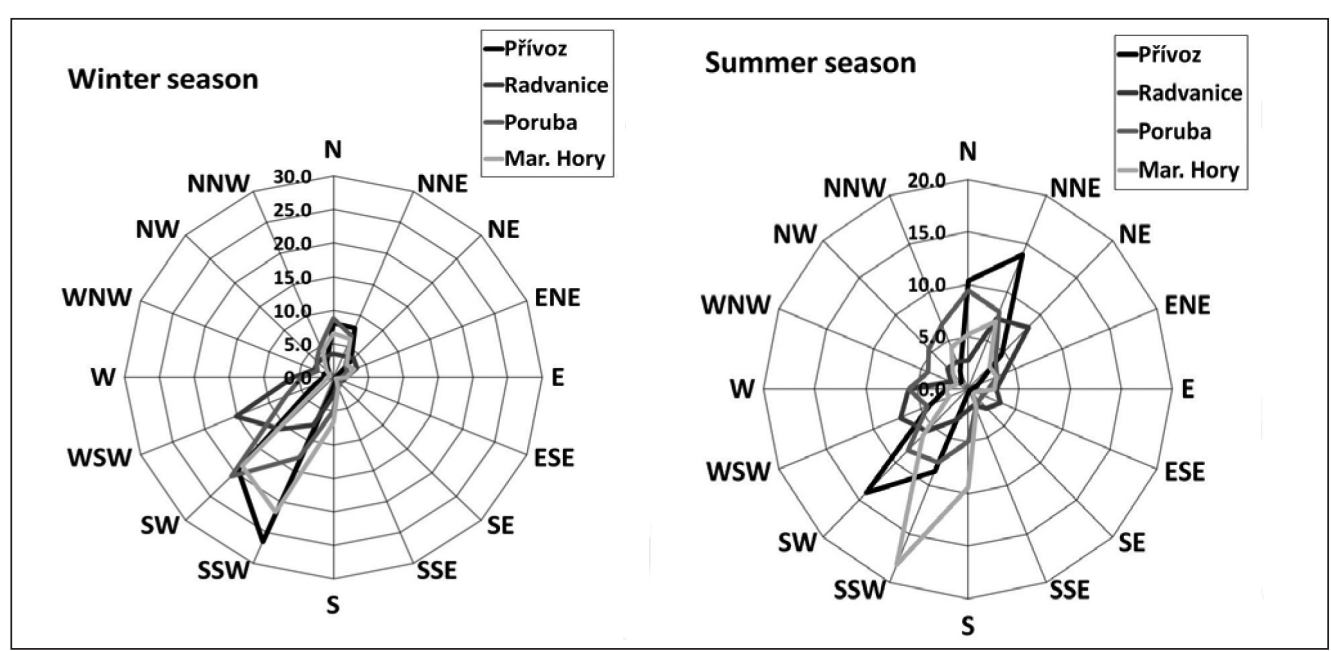

Fig. 2. Wind roses in the territory of Ostrava - graphical representation of the relative frequency of wind directions in winter and summer season. 
Table 2. Overview of annual average concentrations and $98 \%$ quantiles of daily $P M_{10}$ concentrations

\begin{tabular}{|c|c|c|c|c|c|c|c|}
\hline \multirow[b]{2}{*}{ Year } & \multicolumn{4}{|c|}{$\begin{array}{l}\text { Annual average concentrations } \\
{\left[\left[\mu \mathrm{g} / \mathrm{m}^{3}\right]\right.}\end{array}$} & \multicolumn{3}{|c|}{$\begin{array}{l}98 \% \text { quantiles of daily concentrations } \\
{\left[\left[\mathrm{\mu g} / \mathrm{m}^{3}\right]\right.}\end{array}$} \\
\hline & OVA 1 & OVA 2 & OVA 3 & OVA & OVA 1 & OVA 2 & OVA 3 \\
\hline 2013 & 35.50 & 41.67 & 46.80 & 42.99 & 128.00 & 163.10 & 159.80 \\
\hline 2012 & 35.10 & 41.60 & 43.47 & 41.47 & 140.00 & 182.50 & 180.50 \\
\hline 2011 & 28.85 & 43.50 & 45.77 & 40.69 & - & 182.00 & 178.00 \\
\hline 2010 & 34.25 & 47.50 & 52.27 & 45.98 & 175.00 & 234.60 & 199.50 \\
\hline 2009 & 29.80 & 39.00 & 44.37 & 38.71 & 99.00 & 128.70 & 128.80 \\
\hline 2008 & 26.35 & 39.83 & 45.53 & 38.60 & 99.00 & 141.00 & 160.20 \\
\hline 2007 & 24.90 & 39.33 & 50.33 & 39.85 & 87.00 & 121.50 & 144.30 \\
\hline 2006 & 37.50 & 46.17 & 55.07 & 48.74 & 136.00 & 165.40 & 205.30 \\
\hline 2005 & 34.65 & 51.93 & 55.53 & 48.96 & 128.00 & 159.90 & 167.84 \\
\hline 2004 & 31.67 & 50.23 & 38.75 & 43.76 & 117.00 & 153.00 & 158.84 \\
\hline 2003 & 40.71 & 52.81 & 54.18 & 49.62 & 136.80 & 171.70 & 179.90 \\
\hline 2002 & 35.67 & 43.00 & 47.25 & 42.50 & 129.71 & 181.10 & 207.10 \\
\hline 2001 & 37.00 & 44.67 & 45.25 & 43.22 & - & 144.90 & 167.50 \\
\hline 2000 & 30.50 & 38.33 & 39.25 & 37.00 & a) 79.00 & a) 91.00 & 111.00 \\
\hline 1999 & 30.00 & 36.50 & 36.00 & 34.75 & a) 80.00 & a) 94.00 & 100.30 \\
\hline 1998 & 29.00 & 38.00 & 37.50 & 35.63 & a) 104.00 & a) 109.00 & 119.10 \\
\hline 1997 & 34.00 & 44.50 & 54.50 & 44.33 & a) 105.00 & a) 157.00 & 229.40 \\
\hline 1996 & 48.47 & 53.85 & 60.04 & 55.41 & 113.70 & b) 107.01 & 139.84 \\
\hline 1995 & 40.57 & 32.22 & 46.71 & 40.82 & 102.14 & b) 74.05 & 132.54 \\
\hline 1994 & 39.40 & 46.08 & 44.14 & 43.48 & 152.82 & 155.47 & 123.85 \\
\hline 1993 & 45.77 & 48.88 & 58.25 & 51.70 & 147.74 & b) 123.73 & 153.22 \\
\hline 1992 & 40.99 & 48.74 & 53.05 & 47.59 & 138.62 & b) 107.98 & 134.37 \\
\hline 1991 & 47.00 & 59.30 & 68.10 & 59.13 & 165.38 & b) 135.58 & 206.72 \\
\hline 1990 & 49.08 & 57.25 & 68.42 & 61.20 & 122.21 & b) 121.42 & 173.28 \\
\hline 1989 & 54.58 & 62.00 & 73.99 & 65.68 & 127.07 & b) 145.98 & 178.75 \\
\hline 1988 & 48.52 & 53.66 & 71.94 & 63.37 & - & b) 123.91 & 161.12 \\
\hline 1987 & 57.08 & 69.43 & 80.85 & 71.25 & 181.79 & b) 148.29 & 234.08 \\
\hline 1986 & 61.77 & 67.31 & 85.21 & 72.81 & 188.48 & b) 185.93 & 261.44 \\
\hline 1985 & 65.02 & 77.44 & 89.17 & 77.21 & 266.30 & b)206.84 & 297.31 \\
\hline 1984 & 64.01 & - & 88.20 & 78.52 & 217.06 & - & 231.65 \\
\hline 1983 & - & - & - & - & - & - & - \\
\hline 1982 & 62.09 & 84.33 & 95.41 & 84.31 & 165.98 & 240.77 & 308.26 \\
\hline 1981 & 48.27 & 67.70 & 86.32 & 74.99 & 164.16 & 194.56 & 238.94 \\
\hline 1980 & 56.35 & 77.09 & 95.77 & 81.24 & 194.56 & 243.20 & 249.28 \\
\hline 1979 & 56.11 & 73.76 & 96.11 & 75.32 & 103.36 & 194.56 & 206.72 \\
\hline 1978 & 49.59 & 69.69 & 86.02 & 74.87 & 158.08 & 194.56 & 218.88 \\
\hline 1977 & 49.74 & 66.39 & 82.79 & 69.04 & 164.16 & 164.16 & 218.88 \\
\hline 1976 & 64.12 & 72.24 & 84.58 & 79.11 & 218.88 & 188.48 & 255.36 \\
\hline 1975 & 70.34 & 62.91 & 75.85 & 72.77 & 176.32 & 170.24 & 212.80 \\
\hline 1974 & 76.76 & 64.23 & 74.87 & 72.10 & 212.80 & 188.48 & 200.64 \\
\hline 1973 & 69.14 & 80.64 & 73.07 & 75.31 & 200.64 & 352.64 & 249.28 \\
\hline 1972 & 76.39 & 87.81 & 88.79 & 84.33 & 243.20 & 285.76 & 243.20 \\
\hline LV/GV & \multicolumn{4}{|c|}{$40 / 20$} & \multicolumn{3}{|c|}{$50 / 50$} \\
\hline
\end{tabular}

a) $98 \%$ quantiles of monthly concentrations; ${ }^{b} 95 \%$ quantiles of daily concentrations; LV - limit value according the Directive of the European Parliament and the Council Directive 2008/50; GV - WHO guideline value 


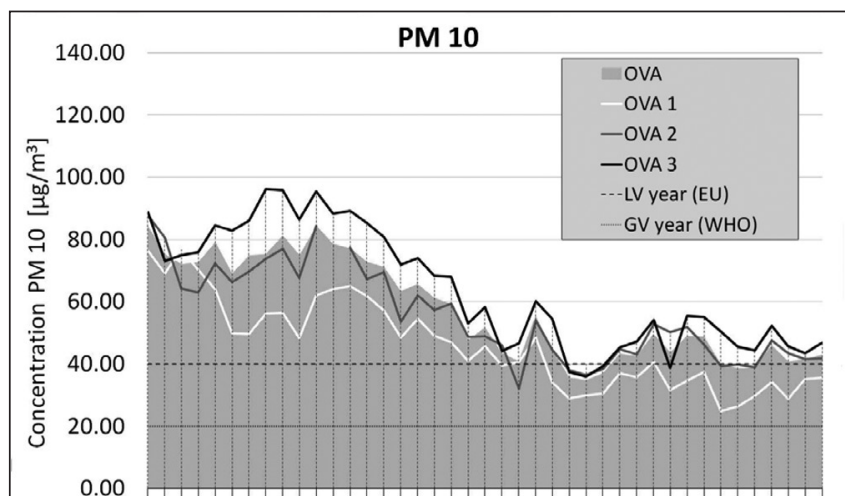

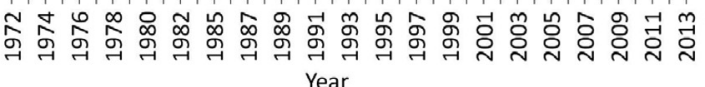

Fig. 3. Annual average concentrations of $P M_{10}$ particles in Ostrava.

LV year (EU) - limit value according to the Directive of the European Parliament and the Council Directive 2008/50, LV year $(E U)=40\left[\mu \mathrm{g} / \mathrm{m}^{3}\right]$ for a calendar year GV year $(\mathrm{WHO})-\mathrm{WHO}$ guideline value, GV year $(\mathrm{WHO})=20\left[\mu \mathrm{g} / \mathrm{m}^{3}\right]$ for a calendar year

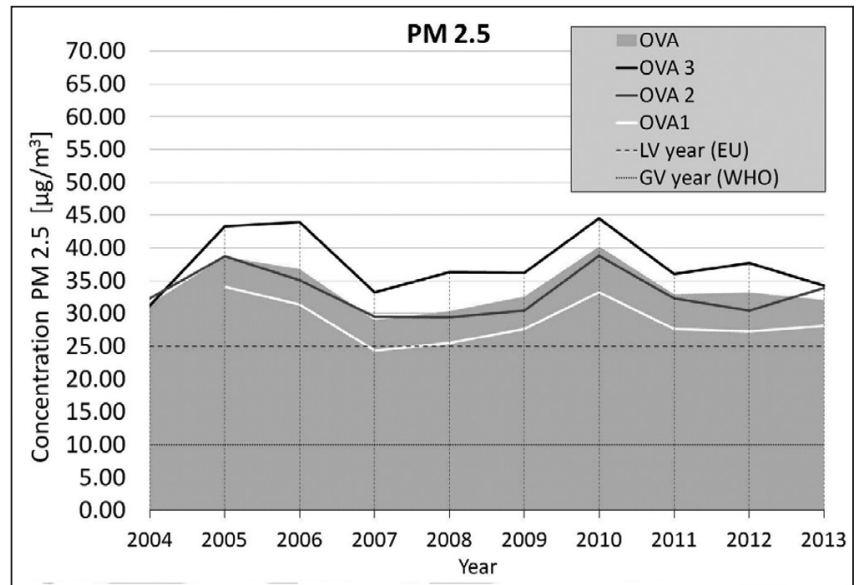

Fig. 4. Annual average concentrations of $P M_{2.5}$ particles in Ostrava.

LV year (EU) - limit value according to the Directive of the European Parliament and the Council Directive 2008/50, LV year $(E U)=25\left[\mu \mathrm{g} / \mathrm{m}^{3}\right]$ for a calendar year GV year $(\mathrm{WHO})-\mathrm{WHO}$ guideline value, GV year $(\mathrm{WHO})=10\left[\mu \mathrm{g} / \mathrm{m}^{3}\right]$ for a calenda year station TOZRA (13). According to the Information System of Air Quality of the Czech Hydrometeorological Institute from the years 2004-2013, the proportion of $\mathrm{PM}_{2.5} / \mathrm{PM}_{10}$ is equal to 0.78 (with the range of values from 0.71 to 0.81 ). As for $\mathrm{PM}_{2.5}$ significant changes in that proportion due to changes in technology and the historical development of pollution sources can be expected. The proportion of fractions is not constant during the year seasons. Higher values were detected in the winter season (14). For this reason, the measured concentrations of total suspended particles TSP and $\mathrm{PM}_{10}$ were not converted to $\mathrm{PM}_{25}$ before 2004.

The overview of measurements of sulphur dioxide $\left(\mathrm{SO}_{2}\right)$ from 1970 to 2013 can be found in Figure 5 and in Table 4.

In Figure 6 and in Table 5 concentrations of nitrogen dioxide are presented. Since 1985 the total nitrogen oxides $\left(\mathrm{NO}_{\mathrm{x}}\right)$, i.e. the sum of concentrations of nitric oxide (NO) and nitrogen dioxide $\left(\mathrm{NO}_{2}\right)$, have been measured. The data from 1985 to 1993 presented here were converted into $\mathrm{NO}_{2}$. The conversion rate was based on the share of $\mathrm{NO}_{2} / \mathrm{NO}$ identified in the period from

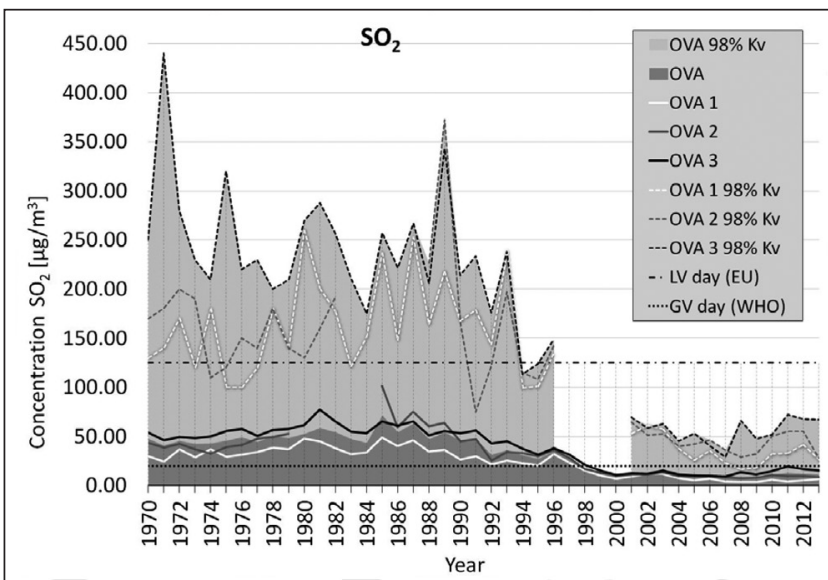

Fig. 5. Annual average concentrations and $98 \%$ quintiles of daily $\mathrm{SO}_{2}$ concentrations in Ostrava.

LV day (EU) - limit value according to the Directive of the European Parliament and the Council Directive 2008/50, LV day $(E U)=125\left[\mu \mathrm{g} / \mathrm{m}^{3}\right]$ in 24-hours, that may be exceeded at maximum 3 times/a year

GV day $(\mathrm{WHO})-$ WHO guideline value, GV day $(\mathrm{WHO})=20\left[\mu \mathrm{g} / \mathrm{m}^{3}\right]$ in 24-hours

Table 3. Overview of annual average concentrations and $98 \%$ quantiles of daily $P M_{2.5}$ concentrations

\begin{tabular}{|c|c|c|c|c|c|c|c|}
\hline \multirow[b]{2}{*}{ Year } & \multicolumn{4}{|c|}{$\begin{array}{l}\text { Annual average concentrations } \\
\qquad\left[\mu \mathrm{g} / \mathrm{m}^{3}\right]\end{array}$} & \multicolumn{3}{|c|}{$\begin{array}{l}98 \% \text { quantiles of daily concentrations } \\
{\left[\left[\mu \mathrm{g} / \mathrm{m}^{3}\right]\right.}\end{array}$} \\
\hline & OVA 1 & OVA 2 & OVA 3 & OVA & OVA 1 & OVA 2 & OVA 3 \\
\hline 2013 & 28.1 & 33.9 & 34.3 & 32.1 & 112.0 & 118.7 & 154.7 \\
\hline 2012 & 27.3 & 30.4 & 37.7 & 33.3 & 124.0 & 138.2 & 164.6 \\
\hline 2011 & 27.6 & 32.3 & 36.0 & 33.0 & 103.0 & 121.9 & 125.8 \\
\hline 2010 & 33.2 & 38.8 & 44.6 & 40.3 & 148.0 & 187.1 & 176.5 \\
\hline 2009 & 27.6 & 30.4 & 36.3 & 32.6 & 87.0 & 98.5 & 112.6 \\
\hline 2008 & 25.5 & 29.4 & 36.3 & 30.4 & 85.0 & 109.4 & 124.8 \\
\hline 2007 & 24.4 & 29.5 & 33.2 & 29.0 & 72.0 & 91.6 & 91.6 \\
\hline 2006 & 31.4 & 35.1 & 44.0 & 36.8 & 110.0 & 136.3 & 162.6 \\
\hline 2005 & 34.1 & 38.7 & 43.3 & 38.7 & 98.0 & 123.0 & 123.0 \\
\hline 2004 & - & 32.3 & 31.2 & 31.5 & - & 105.2 & 114.7 \\
\hline LV/GV & \multicolumn{4}{|c|}{$25 / 10$} & \multicolumn{3}{|c|}{$-/ 25$} \\
\hline
\end{tabular}

LV - limit value according to the Directive of the European Parliament and the Council Directive 2008/50; GV - WHO guideline value 
Table 4. Overview of annual average concentrations and $98 \%$ quantiles of daily $\mathrm{SO}_{2}$ concentrations

\begin{tabular}{|c|c|c|c|c|c|c|c|}
\hline \multirow{2}{*}{ Year } & \multicolumn{4}{|c|}{ Annual average concentrations $\left[\mu \mathrm{g} / \mathrm{m}^{3}\right]$} & \multicolumn{3}{|c|}{$98 \%$ quantiles of daily concentrations $\left[\mu \mathrm{g} / \mathrm{m}^{3}\right]$} \\
\hline & OVA 1 & OVA 2 & OVA 3 & OVA & OVA 1 & OVA 2 & OVA 3 \\
\hline 2013 & 6.3 & 8.5 & 15.0 & 11.4 & 26.3 & 27.8 & 67.4 \\
\hline 2012 & 5.2 & 9.9 & 16.6 & 12.1 & 41.4 & 55.1 & 67.6 \\
\hline 2011 & 4.3 & 9.5 & 19.5 & 13.0 & 32.4 & 55.5 & 72.2 \\
\hline 2010 & 5.7 & 11.0 & 14.4 & 11.2 & 32.3 & 50.4 & 52.1 \\
\hline 2009 & 3.7 & 7.9 & 11.1 & 8.3 & 17.6 & 32.5 & 47.6 \\
\hline 2008 & 3.4 & 7.4 & 13.7 & 8.8 & 17.0 & 28.8 & 66.0 \\
\hline 2007 & 4.3 & 8.6 & 8.9 & 8.0 & 22.7 & 36.1 & 29.1 \\
\hline 2006 & 6.7 & 10.2 & 9.9 & 9.5 & 35.5 & 46.5 & 40.7 \\
\hline 2005 & 5.2 & 9.6 & 10.1 & 9.0 & 25.5 & 42.4 & 53.3 \\
\hline 2004 & 7.3 & 9.8 & 11.3 & 9.7 & 37.6 & 40.2 & 45.4 \\
\hline 2003 & 11.6 & 13.7 & 14.9 & 13.6 & 57.4 & 52.7 & 62.9 \\
\hline 2002 & 12.3 & 11.5 & 12.1 & 12.0 & 61.1 & 51.3 & 58.3 \\
\hline 2001 & 8.9 & 11.5 & 12.4 & 11.4 & 52.8 & 64.5 & 69.7 \\
\hline 2000 & 7.0 & 11.0 & 10.6 & 9.9 & a) 31.0 & a) 37.0 & a) 35.0 \\
\hline 1999 & 10.0 & 12.7 & 15.0 & 12.6 & a) 37.0 & a) 39.0 & a) 53.0 \\
\hline 1998 & 15.0 & 17.0 & 21.0 & 17.6 & a) 75.0 & a) 70.0 & a) 75.0 \\
\hline 1997 & 23.5 & 28.0 & 31.3 & 28.2 & a) 134.0 & a) 126.0 & a) 129.0 \\
\hline 1996 & 31.9 & 36.3 & 38.1 & 34.9 & 135.5 & 142.1 & 148.8 \\
\hline 1995 & 20.3 & 30.1 & 31.5 & 27.3 & 100.6 & 108.0 & 123.8 \\
\hline 1994 & 22.6 & 33.0 & 37.5 & 31.0 & 99.4 & 114.9 & 113.0 \\
\hline 1993 & 25.7 & 34.4 & 44.9 & 36.2 & 238.4 & 197.1 & 238.0 \\
\hline 1992 & 21.5 & 25.7 & 43.2 & 31.2 & 142.8 & 121.7 & 176.0 \\
\hline 1991 & 29.8 & 47.4 & 56.2 & 47.4 & 178.5 & 74.9 & 234.0 \\
\hline 1990 & 26.5 & 45.3 & 53.6 & 45.7 & 167.4 & 166.9 & 214.0 \\
\hline 1989 & 36.6 & 63.5 & 55.7 & 54.1 & 218.0 & 372.5 & 343.0 \\
\hline 1988 & 34.8 & 60.5 & 51.0 & 47.3 & 164.0 & 226.6 & 206.0 \\
\hline 1987 & 46.5 & 75.4 & 65.6 & 63.0 & 253.0 & b) 275.1 & 267.0 \\
\hline 1986 & 40.0 & 59.3 & 61.2 & 54.3 & 148.0 & b) 202.0 & 222.0 \\
\hline 1985 & 48.8 & 101.5 & 65.3 & 71.2 & 237.0 & b) 336.2 & 257.0 \\
\hline 1984 & 33.6 & - & 53.3 & 43.5 & 151.0 & - & 175.0 \\
\hline 1983 & 32.1 & - & 55.0 & 47.4 & 121.0 & - & 211.0 \\
\hline 1982 & 37.9 & - & 65.3 & 54.3 & 177.0 & 192.0 & 256.0 \\
\hline 1981 & 45.2 & 47.2 & 77.1 & 58.4 & 200.0 & 160.0 & 288.0 \\
\hline 1980 & 48.1 & - & 61.5 & 52.6 & 260.0 & 130.0 & 270.0 \\
\hline 1979 & 37.1 & 53.0 & 57.6 & 48.5 & 140.0 & 140.0 & 210.0 \\
\hline 1978 & 38.3 & 49.6 & 56.4 & 50.3 & 180.0 & 180.0 & 200.0 \\
\hline 1977 & 34.0 & 47.8 & 50.4 & 44.5 & 120.0 & 140.0 & 230.0 \\
\hline 1976 & 31.5 & 41.1 & 57.5 & 49.1 & 100.0 & 150.0 & 220.0 \\
\hline 1975 & 29.2 & 39.4 & 55.5 & 45.7 & 100.0 & 120.0 & 320.0 \\
\hline 1974 & 36.8 & 32.7 & 50.2 & 42.9 & 180.0 & 110.0 & 210.0 \\
\hline 1973 & 28.7 & 37.0 & 48.5 & 42.4 & 120.0 & 190.0 & 230.0 \\
\hline 1972 & 36.9 & 42.2 & 49.2 & 45.5 & 170.0 & 200.0 & 280.0 \\
\hline 1971 & 24.5 & 38.4 & 46.5 & 40.7 & 140.0 & 180.0 & 440.0 \\
\hline 1970 & 29.8 & 43.6 & 53.8 & 47.8 & 130.0 & 170.0 & 250.0 \\
\hline LV/GV & \multicolumn{4}{|c|}{$-1-$} & \multicolumn{3}{|c|}{$125 / 20$} \\
\hline
\end{tabular}

a) $98 \%$ quantiles of monthly concentrations, ${ }^{\text {b) }} 95 \%$ quantiles of daily concentrations; LV - limit value according to the Directive of the European Parliament and the Counci Directive 2008/50; GV - WHO guideline value 
1995-2013 (16) as follows: 0.53 (range of values from 0.47 to 0.75 ) for OVA 1, 0.67 (values ranging from 0.62 to 0.74 ) OVA 2, and 0.7 (range of 0.59 to 0.8 ) for OVA 3. Since $1994 \mathrm{NO}_{2}$ has been already measured separately.

The measured concentrations of ozone and carbon monoxide are presented in Table 6 .

In Tables 7 and 8 annual average concentrations of metals in the fraction $\mathrm{PM}_{10}$, which are monitored regularly are presented. The overview of all identified compounds can be found in Table 9.

Table 10 presents overview of annual average concentrations of carcinogenic benzene and benzo[a]pyrene.

A variety of organic substances was identified in the Ostrava environment; their summary can be found in Table 11 .
The calculated potential health risks in a connection with longterm and short-term exposure of $\mathrm{PM}_{10}$ and $\mathrm{PM}_{25}$ are presented in Tables 12 and 13.

Summary of the carcinogenic risk of arsenic, benzene and benzo[a]pyrene, according the WHO (10) and US EPA (30), is presented in Table 14.

\section{DISCUSSION}

The presented results demonstrate that in Ostrava a very slight airflow or calm is dominant (up to $36 \%$ of the relative frequency) with an average speed of $1.5-2 \mathrm{~m} / \mathrm{s}$. The prevailing wind direction is the southwest with about $26 \%$ of the relative frequency.

Table 5. Overview of annual average concentrations and $98 \%$ quantiles of daily $\mathrm{NO}_{2}$ concentrations

\begin{tabular}{|c|c|c|c|c|c|c|c|}
\hline \multirow[t]{2}{*}{ Year } & \multicolumn{4}{|c|}{$\begin{array}{l}\text { Annual average concentrations } \\
{\left[\mu \mathrm{gg} / \mathrm{m}^{3}\right]}\end{array}$} & \multicolumn{3}{|c|}{$\begin{array}{l}98 \% \text { quantiles of daily concentrations } \\
{\left[\left[\mathrm{\mu g} / \mathrm{m}^{3}\right]\right.}\end{array}$} \\
\hline & OVA 1 & OVA 2 & OVA 3 & OVA & OVA 1 & OVA 2 & OVA 3 \\
\hline 2013 & 19.20 & 22.55 & 23.43 & 22.43 & 44.60 & 55.10 & 58.20 \\
\hline 2012 & - & 24.57 & 26.37 & 25.47 & - & 65.80 & 59.20 \\
\hline 2011 & 20.20 & 23.60 & 26.50 & 24.36 & 46.30 & 59.70 & 58.80 \\
\hline 2010 & 19.50 & 26.80 & 27.03 & 25.86 & 50.40 & 74.40 & 73.00 \\
\hline 2009 & 17.90 & 23.83 & 25.67 & 23.77 & 39.30 & 53.30 & 54.50 \\
\hline 2008 & 18.50 & 24.55 & 27.53 & 25.03 & 37.90 & 51.70 & 54.30 \\
\hline 2007 & 20.20 & 23.53 & 26.63 & 24.39 & 47.80 & 50.80 & 51.90 \\
\hline 2006 & 22.40 & 26.20 & 28.93 & 26.83 & 64.60 & 67.90 & 75.20 \\
\hline 2005 & 24.70 & 26.37 & 30.10 & 27.73 & 73.00 & 60.70 & 66.00 \\
\hline 2004 & 21.75 & 24.70 & 25.95 & 24.60 & 48.90 & 59.60 & 54.10 \\
\hline 2003 & 24.38 & 27.49 & 26.78 & 26.27 & 60.80 & 65.00 & 65.90 \\
\hline 2002 & 25.00 & 27.50 & 25.25 & 25.75 & 62.20 & 61.30 & 67.00 \\
\hline 2001 & 28.00 & 25.50 & 28.25 & 27.43 & 58.40 & 61.40 & 61.20 \\
\hline 2000 & 27.00 & 24.00 & 27.75 & 26.57 & a) 46.00 & a) 44.0 & 52.00 \\
\hline 1999 & 25.00 & 28.33 & 25.00 & 26.67 & a) 45.00 & a) 53.00 & 50.30 \\
\hline 1998 & 26.00 & 28.67 & 27.00 & 27.67 & a) 58.00 & a) 56.00 & 52.80 \\
\hline 1997 & 24.00 & 28.00 & 31.00 & 27.60 & a) 72.00 & a) 75.00 & 56.00 \\
\hline 1996 & 32.66 & 32.53 & 31.83 & 32.28 & 76.13 & 81.20 & 67.91 \\
\hline 1995 & 29.39 & 28.89 & 28.03 & 28.80 & 67.21 & 67.17 & 62.68 \\
\hline 1994 & 20.55 & 41.70 & 34.36 & 32.20 & b) 46.91 & b) 91.25 & b) 89.88 \\
\hline 1993 & 20.62 & 33.03 & 32.59 & 30.81 & b) 46.22 & b) 72.36 & b) 67.20 \\
\hline 1992 & 17.76 & 30.19 & 31.57 & 27.03 & b) 41.39 & ${ }^{b)} 66.33$ & b) 58.31 \\
\hline 1991 & 20.78 & 35.85 & 37.21 & 33.79 & b) 46.80 & b) 86.56 & b) 80.43 \\
\hline 1990 & 21.36 & 46.21 & 48.34 & 42.78 & b) 43.46 & b) 121.94 & b) 107.28 \\
\hline 1989 & 17.81 & 46.32 & 51.17 & 43.18 & b) 48.12 & b) 124.29 & b) 113.05 \\
\hline 1988 & 17.86 & 39.53 & 33.42 & 32.75 & b) 49.08 & b) 95.27 & b) 89.39 \\
\hline 1987 & - & 46.28 & 38.71 & 42.49 & - & b) 91.25 & b) 89.88 \\
\hline 1986 & - & 47.20 & 41.09 & 44.15 & - & b) 107.33 & b) 74.17 \\
\hline 1985 & - & 42.03 & 47.72 & 44.31 & - & b) 101.77 & b) 116.76 \\
\hline LV/GV & \multicolumn{4}{|c|}{$40 / 40$} & \multicolumn{3}{|c|}{$200 / 200$} \\
\hline
\end{tabular}

a) $98 \%$ quantiles of monthly concentrations; ${ }^{b} 95 \%$ quantiles of daily concentrations; LV - limit value according to the Directive of the European Parliament and the Council Directive 2008/50; GV - WHO guideline value 


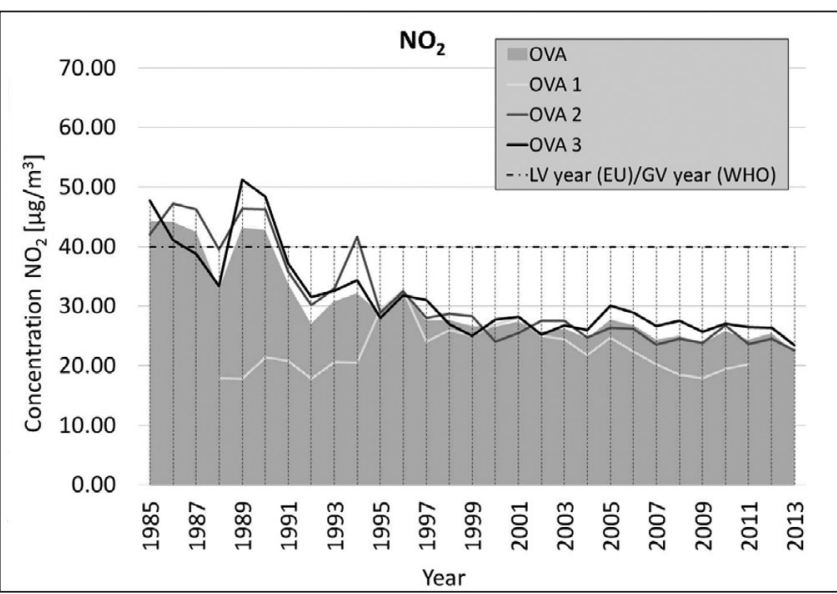

Fig. 6. Annual average $\mathrm{NO}_{2}$ concentrations in Ostrava.

LV year (EU)/GV year (WHO) - limit value according to the Directive of the European Parliament and the Council Directive 2008/50, coinciding with the WHO guideline value, $\mathrm{LV}$ year $(\mathrm{EU}) / \mathrm{GV}$ year $(\mathrm{WHO})=40\left[\mu \mathrm{g} / \mathrm{m}^{3}\right]$ for a calendar year.

The second most frequent wind direction is the north one but its maximum relative frequency is less significant and reaches up to 14\% (Fig. 2). This fact, together with the geographical conditions of the Upper Silesian Basin, shows that the citizens of Ostrava with all its significant emission sources have been exposed to relatively high concentrations of pollutants in comparison to other similar cities (26).

During the study period it was detected that annual average in case of followed air pollutants' concentrations ranged as follows: of $\mathrm{PM}_{10}$ from 25 to $96 \mu \mathrm{g} / \mathrm{m}^{3}$ and $\mathrm{PM}_{2.5}$ from 24 to $45 \mu \mathrm{g}$ / $\mathrm{m}^{3} ; \mathrm{SO}_{2}$ from 3.4 to $101.5 \mu \mathrm{g} / \mathrm{m}^{3} ; \mathrm{NO}_{2}$ from 17.76 to $51.17 \mu \mathrm{g} /$ $\mathrm{m}^{3}$; benzene from 0.24 to $9.2 \mu \mathrm{g} / \mathrm{m}^{3}$; benzo[a]pyrene from 2.1 to $14 \mathrm{ng} / \mathrm{m}^{3}$; arsenic from 1.2 to $9.5 \mathrm{ng} / \mathrm{m}^{3}$. Since the turn of the $80 \mathrm{~s}$ and 90 s of the 20th century trend of air pollutant concentrations has been decreasing until the turn of millennium, when the trend stopped and it has been constant until present time. The significant improvement of air pollution is mainly associated with reduction of the pollutants and gradual changes of technological processes in industry.

Summary of the long time series results shown in this work confirmed that the most serious pollutant in the evaluated locality in terms of health risks is airborne dust and a number of carcinogenic substances.

Measured concentrations of $\mathrm{PM}_{10}$ and $\mathrm{PM}_{2.5}$ (Tables 2 and 3) highly exceed the recommended WHO guidance values (12), i.e. the annual/daily averages $20 / 50 \mu \mathrm{g} / \mathrm{m}^{3}$ for $\mathrm{PM}_{10}$ and $10 / 25 \mu \mathrm{g} /$ $\mathrm{m}^{3}$ for $\mathrm{PM}_{2,5}$.

Health risks related to these exposures are numerous; it is primarily an increase of the total and specific mortality and morbidity of some diseases $(27,28)$ (Table 12 and 13).

An increase of mortality in all age groups, increase of the number of hospital admissions for cardiovascular and respiratory problems, worsening of asthma disorders in asthmatic children and adolescents can be expected among the acute effects. In relationship with the chronic effects general increase in adult mortality, excess of mortality from cerebrovascular and cardiovascular disease, mortality for chronic obstructive pulmonary disease and lung, trachea and bronchi cancer mortality, and further increase of bronchitis prevalence in children aged 6-12 years, and increase incidence of chronic bronchitis in adults are expected (28).

Table 6. Overview of maximum 8-hour average ozone and CO concentrations in the air

\begin{tabular}{|c|c|c|c|c|c|c|}
\hline \multirow{2}{*}{ Year } & \multicolumn{3}{|c|}{ Ozone $\left[\mu \mathrm{g} / \mathrm{m}^{3}\right]$} & \multicolumn{3}{|c|}{$\mathrm{CO}\left[\mu \mathrm{g} / \mathrm{m}^{3}\right]$} \\
\hline & OVA 1 & OVA 2 & OVA 3 & OVA 1 & OVA 2 & OVA 3 \\
\hline 2013 & - & 183 & 178 & - & 2988 & 4250 \\
\hline 2012 & - & 158 & 146 & - & - & 3971 \\
\hline 2011 & - & 145 & 149 & - & - & 3419 \\
\hline 2010 & - & 172 & 159 & - & - & 5459 \\
\hline 2009 & - & 148 & 158 & - & - & 4912 \\
\hline 2008 & - & 149 & - & - & 2792 & 5023 \\
\hline 2007 & - & 186 & - & - & 2711 & 4632 \\
\hline 2006 & - & 168 & - & - & 3500 & 5802 \\
\hline 2005 & - & 143 & 144 & - & 2738 & 4476 \\
\hline 2004 & - & 149 & 126 & 2850 & 3444 & 2329 \\
\hline 2003 & - & 166 & 153 & 3270 & 3494 & 3153 \\
\hline 2002 & - & 147 & 149 & 3757 & 3742 & - \\
\hline 2001 & - & 142 & 137 & 3294 & 4589 & - \\
\hline 2000 & - & 155 & 139 & - & - & - \\
\hline 1999 & - & 132 & 129 & - & - & - \\
\hline 1998 & - & 176 & - & - & - & - \\
\hline 1997 & - & 148 & - & - & - & - \\
\hline LV/GV & \multicolumn{3}{|c|}{$120 / 100$} & \multicolumn{3}{|c|}{$10000 / 10000$} \\
\hline
\end{tabular}

LV - limit value according to the Directive of the European Parliament and the Council Directive 2008/50

GV - WHO guideline value

In both cases the maximum 8-hour daily rolling average is presented 
Table 7. Overview of annual average concentrations of arsenic, cadmium and nickel in the PM ${ }_{10}$ fraction of airborne dust

\begin{tabular}{|c|c|c|c|c|c|c|c|c|c|c|c|c|}
\hline \multirow{2}{*}{ Year } & \multicolumn{4}{|c|}{ As $\left[\mathrm{ng} / \mathrm{m}^{3}\right]$} & \multicolumn{4}{|c|}{$\mathrm{Cd}\left[\mathrm{ng} / \mathrm{m}^{3}\right]$} & \multicolumn{4}{|c|}{$\mathrm{Ni}\left[\mathrm{ng} / \mathrm{m}^{3}\right]$} \\
\hline & OVA 1 & OVA 2 & OVA 3 & OVA & OVA 1 & OVA 2 & OVA 3 & OVA & OVA 1 & OVA 2 & OVA 3 & OVA \\
\hline 2013 & 1.7 & 2.0 & 2.2 & 2.0 & 0.6 & 2.2 & 0.9 & 1.0 & 0.8 & 4.3 & 2.2 & 2.1 \\
\hline 2012 & 1.8 & 2.7 & 2.4 & 2.2 & 0.6 & 4.5 & 1.4 & 1.8 & 0.9 & 6.2 & 2.8 & 2.7 \\
\hline 2011 & 1.5 & - & 2.7 & 2.0 & 0.5 & - & 0.8 & 0.6 & 1.2 & - & 2.1 & 1.6 \\
\hline 2010 & 1.7 & 3.5 & 3.4 & 2.7 & 0.6 & 2.4 & 1.4 & 1.2 & 1.2 & 5.6 & 2.6 & 2.4 \\
\hline 2009 & 1.4 & 8.6 & 3.8 & 3.5 & 0.5 & 2.9 & 1.4 & 1.2 & 1.0 & 6.7 & 3.4 & 2.9 \\
\hline 2008 & 1.2 & 8.0 & 4.6 & 3.6 & 0.5 & 5.7 & 1.7 & 1.8 & 1.0 & 7.2 & 5.7 & 3.9 \\
\hline 2007 & 1.9 & 9.5 & 5.8 & 4.8 & 1.0 & 3.3 & 1.4 & 1.5 & 1.5 & 8.3 & 3.5 & 3.3 \\
\hline 2006 & 2.0 & 8.6 & 6.3 & 5.0 & 1.0 & 3.6 & 1.7 & 1.7 & 1.4 & 10.3 & 2.5 & 3.1 \\
\hline 2005 & 2.1 & - & 4.0 & 3.1 & 1.2 & - & 1.1 & 1.1 & 1.4 & - & 2.0 & 1.7 \\
\hline 2004 & 2.3 & - & 3.8 & 3.1 & 1.3 & - & 1.1 & 1.2 & 1.9 & - & 2.0 & 2.0 \\
\hline 2003 & 6.1 & - & 7.7 & 6.6 & 2.3 & - & 1.3 & 2.1 & - & - & - & - \\
\hline 2002 & 4.9 & 5.7 & 7.1 & 5.5 & 2.5 & 3.0 & 1.9 & 1.7 & 4.9 & 4.0 & 1.9 & 3.8 \\
\hline 2001 & 4.7 & 6.1 & - & 5.1 & 3.8 & 4.6 & - & 4.0 & 10.2 & 47.8 & - & 10.2 \\
\hline 2000 & 6.0 & 9.4 & - & 7.1 & 3.3 & 4.9 & - & 3.7 & 5.8 & 24.3 & - & 12.0 \\
\hline 1999 & 6.6 & 6.3 & - & 6.4 & 3.5 & 8.3 & - & 5.4 & 6.7 & 8.1 & - & 7.1 \\
\hline 1998 & 6.0 & 5.2 & - & 5.6 & 3.0 & 2.6 & - & 2.8 & 45.4 & 34.7 & - & 51.0 \\
\hline 1997 & - & 4.7 & - & 4.7 & 5.9 & 3.2 & - & 4.5 & 6.0 & 22.7 & - & 11.6 \\
\hline LV/GV & \multicolumn{4}{|c|}{$\left.6 / 0.7^{*}\right)$} & \multicolumn{4}{|c|}{$5 / 5$} & \multicolumn{4}{|c|}{$20 / 2.5$} \\
\hline
\end{tabular}

LV - limit value according to the Directive of the European Parliament and the Council Directive 2004/107/ES

GV - WHO guideline value

*According the $\mathrm{WHO}$ there does not exist a safe threshold for arsenic and nickel, presented limit (generally acceptable) corresponds to a carcinogenic risk $10^{-6}$

Table 8. Overview of annual average concentrations of lead and manganese in the $P M_{10}$ fraction of airborne dust

\begin{tabular}{|l|c|c|c|c|c|c|c|c|}
\hline \multirow{2}{*}{ Year } & \multicolumn{9}{|c}{$\mathrm{Pb}\left[\mathrm{ng} / \mathrm{m}^{3}\right]$} & \multicolumn{4}{c|}{ Mn [ng/m } \\
\cline { 2 - 9 } & OVA 1 & OVA 2 & OVA 3 & OVA & OVA 1 & OVA 2 & OVA 3 & OVA \\
\hline 2013 & 16.15 & 76.00 & 37.18 & 36.71 & 7.35 & 54.40 & 49.83 & 38.34 \\
\hline 2012 & 16.80 & 88.50 & 73.20 & 48.83 & 7.80 & 60.60 & 65.60 & 35.45 \\
\hline 2011 & 15.13 & - & 27.95 & 20.26 & 8.73 & - & 28.15 & 16.50 \\
\hline 2010 & 18.63 & 29.90 & 35.23 & 27.36 & 8.00 & 48.60 & 29.83 & 23.16 \\
\hline 2009 & 15.77 & 70.70 & 36.47 & 32.49 & 7.70 & 98.40 & 54.40 & 40.67 \\
\hline 2008 & 16.00 & 55.00 & 42.00 & 32.71 & 8.10 & 83.30 & 60.67 & 41.37 \\
\hline 2007 & 14.70 & 82.60 & 49.68 & 40.68 & 9.50 & 178.10 & 57.25 & 54.45 \\
\hline 2006 & 16.33 & 64.00 & 56.70 & 42.48 & 11.05 & 181.80 & 65.73 & 66.85 \\
\hline 2005 & 21.23 & - & 41.07 & 31.15 & 12.63 & - & 35.17 & 23.90 \\
\hline 2004 & 21.33 & - & 47.90 & 34.62 & 13.23 & - & 32.47 & 22.85 \\
\hline 2003 & 26.97 & - & 41.10 & 30.50 & 34.30 & - & 20.10 & 29.57 \\
\hline 2002 & 26.65 & 28.30 & 58.75 & 22.90 & 31.57 & 23.30 & 51.80 & 36.93 \\
\hline 2001 & 35.57 & 42.70 & - & 36.30 & 40.45 & 56.90 & - & 45.93 \\
\hline 2000 & 37.40 & 65.80 & 64.80 & 48.56 & 33.53 & 74.30 & 88.80 & 52.74 \\
\hline 1999 & 36.87 & 72.15 & 63.80 & 53.12 & 29.87 & 39.50 & 67.20 & 39.26 \\
\hline 1998 & 63.00 & 65.65 & 90.30 & 69.52 & 26.50 & - & 77.50 & 52.00 \\
\hline 1997 & 41.60 & 76.80 & 0.00 & 59.20 & - & - & - & - \\
\hline LV/GV & & & & & & & $150 / 150$ & \\
\hline
\end{tabular}

LV - limit value according to the Directive of the European Parliament and the Council Directive 2008/50 and according the Directive of the European Parliament and the Council Directive 2004/107/ES for manganese

GV - WHO guideline value 
Table 9. Overview of all identified elements and hydrogen sulphide in the air

\begin{tabular}{|c|c|c|c|c|c|c|c|}
\hline \multirow{2}{*}{ Substance } & \multirow{2}{*}{$\begin{array}{l}\text { Concentration range } \\
\text { order }\left[\mu \mathrm{g} \cdot \mathrm{m}^{-3}\right]\end{array}$} & \multicolumn{2}{|c|}{ Carcinogenicity } & \multirow{2}{*}{ Substance } & \multirow{2}{*}{$\begin{array}{c}\text { Concentration range order } \\
{\left[\mu \mathrm{\mu g} \cdot \mathrm{m}^{-3}\right]}\end{array}$} & \multicolumn{2}{|c|}{ Carcinogenicity } \\
\hline & & EPA & IARC & & & EPA & IARC \\
\hline $\mathrm{Ag}$ & $<0.001$ & $D$ & - & $\mathrm{Ni}$ & Table 7 & h) $A$ & h) 1 \\
\hline As & Table 7 & $A$ & 1 & ${ }^{*} \mathrm{P}$ & $<0.01$ & - & - \\
\hline $\mathrm{Al}$ & 0.1 & - & a) 1 & $S$ & 1 & - & - \\
\hline $\mathrm{Ba}$ & $<0.01$ & $\mathrm{D}$ & - & $\mathrm{Pb}$ & Table 8 & i)B2 & i) $2 \mathrm{~A}$ \\
\hline $\mathrm{Bi}$ & $<0.001$ & - & - & $\mathrm{Rb}$ & 0.001 & - & - \\
\hline $\mathrm{Br}$ & $<0.001$ & - & - & $\mathrm{Sb}$ & $<0.01$ & - & e)3 \\
\hline $\mathrm{Ca}$ & 0.1 & - & - & Se & $<0.001$ & D & 3 \\
\hline $\mathrm{Cd}$ & Table 7 & $\mathrm{~B} 1$ & 1 & $\mathrm{Si}$ & 1 & $\mathrm{D}$ & - \\
\hline $\mathrm{Cl}$ & 0.1 & - & - & Sn & $<0.001$ & - & - \\
\hline Co & $<0.001$ & - & $2 B$ & $\mathrm{Sr}$ & 0.001 & - & - \\
\hline $\mathrm{Cr}$ & 0.001 & $\left.{ }^{b)} A / c\right) D$ & b) $1 / 013$ & $\mathrm{Ti}$ & 0.01 & - & f) $2 B$ \\
\hline $\mathrm{Cu}$ & 0.01 & $D$ & - & $\mathrm{TI}$ & $<0.001$ & - & - \\
\hline $\mathrm{Fe}$ & 1 & - & d) 1 & $\mathrm{U}$ & $<0.001$ & - & - \\
\hline $\mathrm{Hg}$ & $<0.001$ & $D$ & 3 & V & 0.001 & - & 9)2B \\
\hline $\mathrm{Mn}$ & Table 8 & $D$ & - & $\mathrm{Zn}$ & 0.1 & $D$ & - \\
\hline Mo & $<0.01$ & - & - & $\mathrm{H}_{2} \mathrm{~S}$ & $<10$ & - & - \\
\hline $\mathrm{Na}$ & 0.1 & - & - & - & - & - & - \\
\hline
\end{tabular}

*Means an analytical group indicator, it is not elemental phosphorus

a)Applicable for production of aluminium

b) Valid for $\mathrm{Cr}^{\mathrm{vl}}$

c) Valid for Cr'II

d)Applicable for professional exposure in the iron and steel industry

e)Valid for antimony trioxide

f) Valid for titanium dioxide

9) Valid for vanadium pentoxide

h) Valid for nickel dust from refineries

i) Valid for inorganic compounds, for organic lead compounds of the Group 2B

Recently, in addition to measurements of fractions $\mathrm{PM}_{10}$ and $\mathrm{PM}_{2.5}$ a number of research projects dealing with the finest particles of airborne dust, so called smoke or nanoparticles according to the new internationally accepted characteristics, have been carried out in EN ISO 13138 and EN ISO 28439. For example, the project of the Institute of Public Health in Ostrava and Technical University in Ostrava within the framework of the programme VaVaI CZ.1.02/5.1.00/10.06301 can be mentioned (15).

In addition to particulate matter also gaseous pollutants were measured. In the seventies and eighties one of the most harmful pollutants was sulphur dioxide, a product of combustion of sulphur containing materials (mostly lignite). It was the first substance that has been monitored since 1970 (Table 4). In the nineties of the 20th century sulphur dioxide began to be considered less significant pollutant in the Ostrava region due to a strong decrease of its concentrations and changes in the organization and financing of monitoring therefore have been made. For this reason, the measurement data from the period 1997-2000 are not available. The health risks of exposure to sulphur dioxide in Ostrava were considered significant in the nineties of the 20th century. Over the years, the WHO has reconsidered the health risks related to the acute effects of this substance with the resulting guideline value of $20 \mu \mathrm{g} / \mathrm{m}^{3}$ for 24-hours concentrations (12), while in the legislation the recommendations were not reflected - the limit for a daily average concentration was set $125 \mu \mathrm{g} / \mathrm{m}^{3}$ (31). It cannot be said with certainty that occasionally exceeded limits recom- mended by the WHO present significant increase of health risk in Ostrava (Table 4). A similar conclusion can be made in case of ozone in the environment of Ostrava (Table 6). Based on a current knowledge about the influence of nitrogen oxides and carbon monoxide on the human body $(12,29)$ concentrations detected in the air in Ostrava (Tables 5 and 6) do not represent any significant risk for the inhabitants of the city.

Approximately in the half of the nineties of the 20th century the public health service conducted the first extensive screening of the airborne dust compounds (17). A number of metals detected were then monitored regularly (Tables 7 and 8). The overview of all identified compounds can be found in Table 9. The content of metals in the fraction $\mathrm{PM}_{10}$ is gradually decreasing. This trend occurs at all monitoring stations placed in order to protect human health. The limit values were not exceeded in the last years (18).

The measurement of the concentrations of carcinogenic benzene, and a number of polycyclic aromatic hydrocarbons (PAH) including benzo[a]pyrene, the most important of them, was launched in 1995 (Table 10) by the Regional health authority in Ostrava (19). PAH were detected in the fraction $\mathrm{PM}_{10}$. Since 2000 these substances have been monitored also by the Czech hydrometeorological institute. In Ostrava, the concentrations of polycyclic aromatic hydrocarbons with a carcinogenic potential have been measured at levels that still represent an unacceptable carcinogenic risk. High exposure lasted for quite a few decades and expected risks seem to be therefore probably real. The carci- 
Table 10. Overview of annual average concentrations of benzene and benzo[a]pyrene in the air

\begin{tabular}{|c|c|c|c|c|c|c|c|c|}
\hline \multirow{2}{*}{ Year } & \multicolumn{4}{|c|}{ Benzene $\left[\mu \mathrm{g} / \mathrm{m}^{3}\right]$} & \multicolumn{4}{|c|}{$\mathrm{B}[\mathrm{a}] \mathrm{P}\left[\mathrm{ng} / \mathrm{m}^{3}\right]$} \\
\hline & OVA 1 & OVA 2 & OVA 3 & OVA & OVA 1 & OVA 2 & OVA 3 & OVA \\
\hline 2013 & 2.2 & 3.3 & 3.3 & 3.1 & 2.9 & 2.9 & 6.4 & 5.0 \\
\hline 2012 & 2.0 & 3.7 & 4.8 & 4.0 & 3.3 & 4.2 & 7.9 & 6.2 \\
\hline 2011 & 2.9 & 4.3 & 6.9 & 5.4 & 3.4 & 3.5 & 7.1 & 5.6 \\
\hline 2010 & 3.2 & 4.1 & 5.7 & 4.8 & 3.8 & 4.4 & 6.7 & 5.7 \\
\hline 2009 & 2.7 & 4.0 & 6.4 & 5.0 & 3.3 & 4.8 & 8.3 & 6.6 \\
\hline 2008 & 3.0 & 4.7 & 6 & 5.1 & 3.5 & 3.9 & 6.5 & 5.4 \\
\hline 2007 & 3.2 & 3.6 & 5.5 & 4.5 & 2.2 & 4.1 & 7.7 & 5.4 \\
\hline 2006 & - & 4.4 & 9.2 & 7.3 & 3.7 & 4.9 & 9.3 & 6.8 \\
\hline 2005 & 2.4 & 3.9 & 7.1 & 5.3 & 3.2 & 4.5 & 9.8 & 6.8 \\
\hline 2004 & 2.3 & 3.1 & 5.2 & 3.8 & 2.1 & 4.3 & 8.3 & 5.8 \\
\hline 2003 & - & - & 8.5 & 8.5 & - & - & 7.9 & 7.9 \\
\hline 2002 & 2.6 & - & 7.0 & 5.5 & 6.2 & - & 6.1 & 6.1 \\
\hline 2001 & - & - & 6.6 & 6.6 & - & - & 6.5 & 6.5 \\
\hline 2000 & - & - & 9.2 & 9.2 & - & - & 4.6 & 4.6 \\
\hline 1999 & - & 5.8 & 8.1 & 7.0 & - & 3.6 & 6.6 & 5.1 \\
\hline 1998 & - & 3.7 & 3.3 & 3.5 & - & 8.3 & 7.4 & 7.9 \\
\hline 1997 & - & - & 0.8 & 0.8 & - & - & 13.4 & 13.4 \\
\hline 1996 & 4.3 & - & 0.2 & 2.3 & 13.8 & - & 14.0 & 13.9 \\
\hline LV/GV & \multicolumn{4}{|c|}{$5.0 / 0.2$} & \multicolumn{4}{|c|}{$1.0 / 0.01$} \\
\hline
\end{tabular}

LV - limit value according to the Directive of the European Parliament and the Council Directive 2008/50

GV - WHO guideline value. According to the WHO there does not exist a safe threshold for benzene and benzo(a)pyrene, presented limit (generally acceptable) corresponds to a carcinogenic risk $10^{-6}$.

Table 11. Overview of identified volatile organic compounds in the air

\begin{tabular}{|c|c|c|}
\hline VOCs & Substances & $\begin{array}{c}\text { Concentrations range } \\
{\left[\mu \mathrm{g} / \mathrm{m}^{3}\right]}\end{array}$ \\
\hline Aliphatic hydrocarbons & $\begin{array}{l}\text { Propane; Butane; 2-Butane; Pentane; Heptane; Hexane; 2-Methylbutane; 2-Methylhexane; } \\
\text { 3-Methylhexane; 2-Methylpentane; 3-Methylpentane; 2-Methyl-1-pentane; 2-Methylpropane; } \\
\text { Octane; Cyclohexane; Methylcyclohexane }\end{array}$ & $10-100$ \\
\hline CFCs (Freons) & $\begin{array}{l}\text { Dichlordifluoromethane; 1,2-dichloro-1-fluoroethane; Trichlorfluromethane; } \\
\text { 1,1,2-Trichloro-1,2,2-trifluorethane }\end{array}$ & $<0.1$ \\
\hline Chlorinated hydrocarbons & 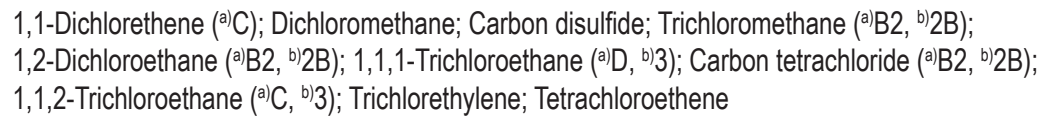 & $<0.1$ \\
\hline Aromatic hydrocarbons & 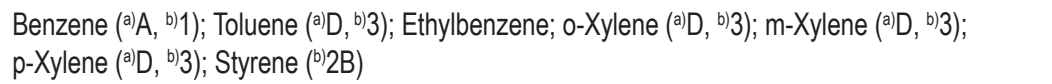 & $1-10$ \\
\hline
\end{tabular}

a) Carcinogenicity group by EPA

${ }^{b}$ Carcinogenicity group by IARC

nogenic risks are likely increased by the contribution of benzene that annual average concentrations regularly and permanently exceeded the acceptable threshold of cancer risk and that is expressed in the immission limit at the level of $5 \mu \mathrm{g} / \mathrm{m}^{3}$ (Table 14).

The real long-term (chronic) negative effects on human health can be also caused by the content of some metals in airborne dust. Although the concentrations have been decreasing in recent years, Tables 7, 8 and 9 show that arsenic, cadmium and nickel exceeded the recommended concentrations being created for health protection, though the lifetime carcinogenic risk of arsenic was not negligible (Table 14).
In addition to the above mentioned extensive systematic monitoring of air pollutants (within the framework of the Automatic immission monitoring of the Czech Hydrometeorological Institute, the National Health Monitoring and the Special monitoring of health status of population in the Ostrava-Karviná region) a number of partial studies with specific focus was carried out in the Ostrava region.

Between 1994 and 1995 the project Silesia was performed by the US Environmental Protection Agency (US EPA), which aim was to determine the potential environmental health risks (air and water) and food risks in the Ostrava agglomeration, and to train 
Table 12. The long-term average health risks expressed as relative risks (RR), i.e. an increase of mortality and morbidity compared to the state with the recommended highest annual concentrations of $P M_{10}\left(20 \mu \mathrm{g} / \mathrm{m}^{3}\right)$ and $P M_{2.5}\left(10 \mu \mathrm{g} / \mathrm{m}^{3}\right)$ according to the WHO in the population of Ostrava

\begin{tabular}{|c|c|c|c|c|c|c|}
\hline \multirow{2}{*}{$\begin{array}{l}\text { Zone } \\
\text { Long-term exposure }\end{array}$} & \multicolumn{2}{|c|}{ OVA 1} & \multicolumn{2}{|c|}{ OVA 2} & \multicolumn{2}{|c|}{ OVA 3} \\
\hline & $\mathrm{PM}_{10}$ & $\mathrm{PM}_{2.5}$ & $\mathrm{PM}_{10}$ & $\mathrm{PM}_{2.5}$ & $\mathrm{PM}_{10}$ & $\mathrm{PM}_{2.5}$ \\
\hline a) $\operatorname{LE}\left[\mu \mathrm{g} / \mathrm{m}^{3}\right]$ & $25-77$ & $24-34$ & $32-88$ & $29-39$ & $36-96$ & $31-45$ \\
\hline Long-term health outcome & \multicolumn{6}{|c|}{ RR range } \\
\hline $\begin{array}{l}\left.{ }^{b}\right) M>30 \\
R R_{10}=1.062\end{array}$ & unavailable & $1.09-1.15$ & unavailable & $1.12-1.18$ & unavailable & $1.13-1.22$ \\
\hline c) $\mathrm{CD}, \mathrm{IHD}, \mathrm{COPD}>30$ & unavailable & $1.14-1.20$ & unavailable & $1.17-1.22$ & unavailable & $1.18-1.25$ \\
\hline d) $L C>30$ & unavailable & $1.21-1.31$ & unavailable & $1.26-1.35$ & unavailable & $1.28-1.39$ \\
\hline $\begin{array}{l}\text { e) } P I M<1 \\
R_{10}=1.04\end{array}$ & $1.02-1.23$ & unavailable & $1.05-1.27$ & unavailable & $1.06-1.30$ & unavailable \\
\hline $\begin{array}{l}\mathrm{RR}_{10}=1.08 \\
\mathrm{f} P \mathrm{~PB}-12(6-18)\end{array}$ & $1.04-1.46$ & unavailable & $1.10-1.54$ & unavailable & $1.13-1.61$ & unavailable \\
\hline $\begin{array}{l}\text { g) } \mid C B>18 \\
R^{R} R_{10}=1.117\end{array}$ & $1.06-1.67$ & unavailable & $1.14-1.80$ & unavailable & $1.19-1.89$ & unavailable \\
\hline
\end{tabular}

a)LE - long-term exposures - range of annual average concentrations (see Tables 2 and 3)

${ }^{\text {b) } M>30}$ - Mortality - all causes. age $30+$ years. $R_{10}=1.062$ per $10 \mu \mathrm{g} / \mathrm{m}^{3}$
c) Mortality, $\mathrm{CD}$ - cerebrovascular disease (includes stroke), IHD - ischaemic heart disease, COPD - chronic obstructive pulmonary disease, $R R=\frac{(x+1)^{0.15515}}{(10+1)^{0.15515}}$
age $30+$ years, $\mathrm{x}$ is concentration of $\mathrm{PM}_{25}$ age $30+$ years, $x$ is concentration of $P M_{2}$

d) $\mathrm{LC}$ - mortality, trachea, bronchus and lung cancer, $R R=\frac{(x+1)^{0.23218}}{(10+1)^{0.23218}}$, age $30+$ years, $\mathrm{x}$ is concentration of $\mathrm{PM}_{2.5}$

e) $\mathrm{PIM}<1$ - Postneonatal (age 1-12 months) infant mortality, all-cause. $\mathrm{RR}_{10}=1.04 \mathrm{per} 10 \mu \mathrm{g} / \mathrm{m}^{3}$

f)PB6-12(6-18) - Prevalence of bronchitis in children, age 6-12 (or 6-18) years. $R_{10}=1.08 \mathrm{per} 10 \mu \mathrm{g} / \mathrm{m}^{3}$

g) $\mid C B>18-$ Incidence of chronic bronchitis in adults (age $18+$ years). $R_{10}=1.117$ per $10 \mu \mathrm{g} / \mathrm{m}^{3}$

Table 13. The short-term average health risks expressed as relative risks (RR), i.e. an increase of mortality and morbidity compared to the state with the recommended highest annual concentrations of $P M_{10}\left(20 \mu \mathrm{g} / \mathrm{m}^{3}\right)$ and $P M_{2.5}\left(10 \mu g / \mathrm{m}^{3}\right)$ according to the WHO in the population of Ostrava

\begin{tabular}{|c|c|c|c|c|c|c|}
\hline Zone & \multicolumn{2}{|c|}{ OVA 1} & \multicolumn{2}{|c|}{ OVA 2} & \multicolumn{2}{|c|}{ OVA 3} \\
\hline Short term exposure & $\mathrm{PM}_{10}$ & $\mathrm{PM}_{2.5}$ & $\mathrm{PM}_{10}$ & $\mathrm{PM}_{2.5}$ & $\mathrm{PM}_{10}$ & $\mathrm{PM}_{2.5}$ \\
\hline h)SE $\left[\mu \mathrm{g} / \mathrm{m}^{3}\right]$ & $87-266$ & $72-124$ & $74-353$ & $92-187$ & $124-308$ & $92-177$ \\
\hline Short-term health outcome & \multicolumn{6}{|c|}{ RR range } \\
\hline $\begin{array}{l}\text { i) } M \text {-all } \\
R_{10}=1.0123\end{array}$ & unavailable & $1,0762-1,1402$ & unavailable & $1,1008-1,2177$ & unavailable & $1,1008-1,2054$ \\
\hline $\begin{array}{l}\text { i) } H A C \text {-all } \\
\mathrm{RR}_{10}=1.0091\end{array}$ & unavailable & $1,0564-1,1037$ & unavailable & $1,0746-1,1610$ & unavailable & $1,0746-1,1519$ \\
\hline $\begin{array}{l}\text { k) HAR-all } \\
\mathrm{RR}_{10}=1.0190\end{array}$ & unavailable & $1,1178-1,2166$ & unavailable & $1,1558-1,3363$ & unavailable & $1,1558-1,3173$ \\
\hline $\begin{array}{l}\text { "IAS5-19 } \\
\mathrm{RR}_{10}=1.0128\end{array}$ & $1,0857-1,3148$ & unavailable & $1,0691-1,4262$ & unavailable & $1,1331-1,3686$ & unavailable \\
\hline
\end{tabular}

h)SE - short-term exposures - range of 98th quantiles (percentiles) 24hour average concentrations (see Tables 2 and 3)

i) M-all - Mortality, all-cause, all ages. $R_{10}=1.0123$ per $10 \mu \mathrm{g} / \mathrm{m}^{3}$

i) HAC-all - Hospital admissions, cardiovascular diseases (CVDs) (includes stroke), all ages. $R_{10}=1.0091 \mathrm{per} 10 \mu \mathrm{g} / \mathrm{m}^{3}$

k)HAR-all - Hospital admissions, respiratory diseases, all ages. $\mathrm{RR}_{10}=1.019 \mathrm{per} 10 \mu \mathrm{g} / \mathrm{m}^{3}$

IIAS5-19 - Incidence of asthma symptoms in asthmatic children aged 5-19 years. $R_{10}=1.0128 \mathrm{per} 10 \mu \mathrm{g} / \mathrm{m}^{3}$

selected professionals in health risk assessment and management (20). The project also included a 30- day study focused on a more detailed description of Ostrava pollution sources (21) and the demonstration project of air quality management (22). Based on the results of these studies significant success in promoting measures of air quality improvement in Ostrava was achieved (e.g. hermetisation of some coke-oven operations).

In the years 1995-1996 more detailed measurements of concentrations of $\mathrm{PM}_{10}$ and $\mathrm{PM}_{2.5}, \mathrm{NO}_{2}$ and $\mathrm{SO}_{2}$ were carried out in the framework of the project CESAR funded by the EU PHARE.
For the first time, the concentrations of $\mathrm{PM}_{25}$ were measured, but the systematic monitoring began only in 2004 . The annual average concentration of $\mathrm{PM}_{10}$ (however measured at places other than stated in Table 1) in this study varied in the range between 64 and $91 \mu \mathrm{g} / \mathrm{m}^{3}$ and $\mathrm{PM}_{2.5}$ varied from 48 to $60 \mu \mathrm{g} / \mathrm{m}^{3}$. The results are available (23).

In 2009, a study dealing with identification of personal exposure to volatile organic compounds (VOCs) in the three industrial cities - Ostrava, Karviná and Havírov - was conducted; as the control area Prague was chosen (24). Passive diffusion samplers 
Table 14. Carcinogenic risk of arsenic, benzene and benzo[a]pyrene in the air for population in Ostrava

\begin{tabular}{|c|c|c|c|c|c|c|c|}
\hline \multirow{3}{*}{\multicolumn{2}{|c|}{$\begin{array}{l}\text { Carcinogenic substance } \\
\text { The unit of carcinogenic risk } \\
{\left[\mu \mathrm{g} / \mathrm{m}^{3}\right]^{-1}}\end{array}$}} & \multicolumn{2}{|c|}{ Arsenic } & \multicolumn{2}{|c|}{ Benzene } & \multicolumn{2}{|c|}{ Benzo[a]pyrene } \\
\hline & & WHO & EPA & WHO & EPA & WHO & EPA \\
\hline & & $1.5^{\star} 10^{-3}$ & $4.3^{*} 10^{-3}$ & $6^{*} 10^{-6}$ & $7.8^{*} 10^{-6}$ & $9 * 10^{-2}$ & $1.1^{*} 10^{-3}$ \\
\hline \multirow{3}{*}{ OVA 1} & $\mathrm{LE}^{\mathrm{a})}\left[\mu \mathrm{g} / \mathrm{m}^{3}\right]$ & \multicolumn{2}{|c|}{$0.0012-0.0066$} & \multicolumn{2}{|c|}{$2.0-4.3$} & \multicolumn{2}{|c|}{$0.0021-0.0138$} \\
\hline & $\operatorname{LICR}\left[10^{-6}\right]^{b)}$ & $2-10$ & $5-28$ & $12-26$ & $16-34$ & $189-1242$ & $2-15$ \\
\hline & LNc) & $0.2-0.9$ & $0.4-2.4$ & $1.0-2.2$ & $1.4-2.9$ & $16.3-107$ & $0.2-1.3$ \\
\hline \multirow{3}{*}{ OVA 2} & $\mathrm{LE}^{\mathrm{a})}\left[\mu \mathrm{g} / \mathrm{m}^{3}\right]$ & \multicolumn{2}{|c|}{$0.0020-0.0095$} & \multicolumn{2}{|c|}{$3.1-5.8$} & \multicolumn{2}{|c|}{$0.0029-0.0083$} \\
\hline & LICR $\left[10^{-6}\right]^{b)}$ & $3-14$ & $9-41$ & $17-35$ & $24-45$ & 261-747 & $3-9$ \\
\hline & $\left.\mathrm{LN}^{c}\right)$ & $0.4-1.9$ & $1.2-5.5$ & $2.3-4.7$ & $3.2-6.0$ & $35.0-100$ & $0.4-1.2$ \\
\hline \multirow{3}{*}{ OVA 3} & $\mathrm{LE}^{\mathrm{a})}\left[\mu \mathrm{g} / \mathrm{m}^{3}\right]$ & \multicolumn{2}{|c|}{$0.0022-0.0077$} & \multicolumn{2}{|c|}{$0.8-9.2$} & \multicolumn{2}{|c|}{$0.0046-0.0139$} \\
\hline & LICR $\left[10^{-6}\right]^{b)}$ & $3-12$ & $10-33$ & $5-55$ & $6-72$ & $414-1251$ & $5-15$ \\
\hline & $\mathrm{LN}^{\mathrm{c})}$ & $0.2-1.0$ & $0.8-2.7$ & $0.4-4.5$ & $0.5-5.9$ & $34.2-103$ & $0.4-1.2$ \\
\hline
\end{tabular}

a) LE - estimation of long-term exposure - range of annual average concentrations in the air (see Tables 7 and 10)

b) LICR - range of individual lifetime carcinogenic risk in $10^{-6}$.

c) LN - range of expected number of new cancers during the life expectancy in each zone of Ostrava (OVA1 - 86,449 inhabitants, OVA2 - 133,994 inhabitants, OVA3 82,526 inhabitants)

were used for the measurements of personal exposure to benzene, toluene, ethylbenzene, meta-, para- and ortho-xylene (hereinafter BTEX). The average detected level of personal BTEX exposure during the two seasons was $7.2 / 34.3 / 4.4 / 16.1 \mu \mathrm{g} / \mathrm{m}^{3}$. In winter, higher levels of benzene were found in Karviná, Ostrava and Prague. The values of personal exposure to BTEX were higher than those found in the stationary monitoring exposures in individual locations.

Similarly, in the same year the personal exposure to carcinogenic polycyclic aromatic hydrocarbons (c-PAHs) conjugated to the dust particles $\leq 2.5 \mu \mathrm{m}\left(\mathrm{PM}_{2.5}\right)$ was monitored in the same locations (25). The active personal monitoring device PV 1.7 for c-PAHs bound in $\mathrm{PM}_{25}$ was used for the measurements. The average personal exposure to PAHs in the winter season was the highest in Karviná $\left(39.1 \mathrm{ng} / \mathrm{m}^{3}\right)$, followed by Ostrava (15.1 ng/ $\left.\mathrm{m}^{3}\right)$ and Prague $\left(4.3 \mathrm{ng} / \mathrm{m}^{3}\right)$. The values detected in winter were significantly higher than the summer values (Karviná $-4.3 \mathrm{ng} / \mathrm{m}^{3}$, Ostrava - $3.0 \mathrm{ng} / \mathrm{m}^{3}$, Havírov - $1.6 \mathrm{ng} / \mathrm{m}^{3}$ and Prague $-1.0 \mathrm{ng} /$ $\left.\mathrm{m}^{3}\right)$. The average detected values of personal exposure to benzo[a] pyrene (winter/summer) were as follows: Karviná - 6.9/0.6 ng/ $\mathrm{m}^{3}$, Ostrava $-2.5 / 0.4 \mathrm{ng} / \mathrm{m}^{3}$, Prague $0.8 / 0.1 \mathrm{ng} / \mathrm{m}^{3}$ and Havírov $-0.2 \mathrm{ng} / \mathrm{m}^{3}$ in summer.

In the year 2011, the study Air Silesia was performed, which aim was to assess the trans-boundary transfer of pollutants in the Upper Silesian Basin between the Czech Republic and Poland (8).

\section{CONCLUSION}

It can be concluded that even a significant reduction of the pollutants concentrations in Ostrava in the nineties of the last century does not mean a required improvement of outdoor air quality to the desired level. Persisting episodes with a very strong short-term increase of the concentration of fine particles, as well as long-term load of these substances on the population is very high. Health risks from such burdens are likely to lead to a higher mortality especially for specific diseases. They increase incidence of respiratory diseases, especially in children, and incidence of some malignant diseases than in case of air quality recommended by the World Health Organization.

\section{REFERENCES}

1. Air quality in Europe - 2014 report. Copenhagen: European Environment Agency (EEA); 2014.

2. Sources of pollution for 2014 District: Ostrava-city [Internet]. Prague: Czech Hydrometeorological Institute; 2016 [cited 2015 Feb 1]. Available from: http://portal.chmi.cz/files/portal/docs/uoco/web_generator/plants/ ostrava_mesto_CZ.html. (In Czech.)

3. Statutory city of Ostrava - official webside [Internet]. Ostrava: Municipality of the city Ostrava, 2014 [cited 2015 May 20]. Emission. Available from: http://www.ostrava.cz/cs/o-meste/zivotni-prostredi/ovzdusi/stavkvality-ovzdusi/emise. (In Czech.)

4. Laža J. Information about traffic in Ostrava 2012 [Internet]. Ostrava: Statutary City of Ostrava; 2013 [cited 2015 Feb 1]. Available from: http://www.ostrava.cz/cs/urad/magistrat/odbory-magistratu/odbordopravy/oddeleni-silnic-mostu-rozvoje-a-organizace-dopravy/informaceo-doprave/c-users-adamekri-desktop-doc-net-2013-roaenka-2012.pdf. (In Czech.)

5. Czech Statistical Office - public database [Internet]. Prague: Czech Statistical Office; 2011 [cited 2015 Feb 1]. Houses and flats according to the results of the census - 2011. Available from: https://vdb.czso.cz/ vdbvo2/faces/cs/index.jsf?page $=$ vystup-objekt\&filtr $=G \sim F \_M \sim F \_Z \sim F$ $\mathrm{R} \sim \mathrm{F} P \sim \mathrm{S} \sim$ null null \&katalog $=30740 \&$ nahled $=\mathrm{N} \& \mathrm{sp}=\mathrm{N} \& \mathrm{z}=\mathrm{T} \& \mathrm{f}=$ 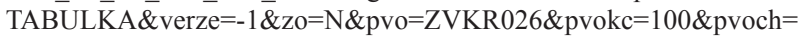 3140\#w.

6. Bílek J, Keder J, Černikovský L, Kotlík B, Lollek V. Analysis of a dependence between the meteorological variables and air quality [Internet]. Ostrava: Regional Institute of Public Health in Ostrava; 2012 [cited 2015 Feb 1]. Available from: https://dycham.ostrava.cz/images/zprava_final_2. pdf.

7. Statutory city of Ostrava - official webside: about Ostrava [Internet]. Ostrava: Municipality of the city Ostrava; 2014 [cited 2015 Feb 1]. Available from: http://www.ostrava.cz/cs/o-meste.

8. Blažek Z. The influence of meteorological conditions on air quality in the border region of Silesia and Moravia. Prague: Czech Hydrometeorological Institute; 2013. (In Czech.)

9. Jiř́k V, Mikeš P, Burdová J. Atmosphere in Ostrava. Review of comprehensive monitoring of noxious substances in 1996 and the historical development of atmospheric contamination in Ostrava from 1985. Hygiena. 1999;44(1):36-50. (In Czech.)

10. World Health Organization. Air quality guidelines for Europe. 2nd ed. Copenhagen: WHO Regional Office for Europe; 2000. 
11. Bogo H, Otero M, Castro P, Ozafran MJ, Kreiner A, Calvo EJ, et al. Study of atmospheric particulate matter in Buenos Aires city. Atmos Environ. 2003 Mar;37(8):1135-47.

12. World Health Organization. Air quality guidelines. Global update 2005: particulate matter, ozone, nitrogen dioxide, and sulphur dioxide. Copenhagen: WHO Regional Office for Europe; 2006.

13. Kazmarová H, editor. System health monitoring of the Czech Republic in relation to the environment: health consequences and risks of air pollution. Expert Report 2013. Prague: National Institute of Public Health; 2014.

14. Air Quality in Czech Republic [Internet]. Prague: Czech Hydrometeorological Institute; 2014 [cited 2015 Feb 1]. Available from: http:// portal.chmi.cz/files/portal/docs/uoco/isko/grafroc/13groc/gr13cz/ IV1_PM CZ.html.

15. Kaličáková Z, Míčka V, Lach K, Danihelka P. Urban air pollution by nanoparticles in Ostrava region. J Phys Conf Ser. 2013;429. pii: 012005.

16. Air pollution and atmospheric deposition in data, the Czech Republic [Internet]. Prague: Czech Hydrometeorological Institute; 2015 [cited 2015 Feb 1]. Available from: http://portal.chmi.cz/files/portal/docs/uoco/isko/ tab_roc/tab_roc_CZ.html.

17. Jiř́k V, Volf J, Němcová V. The atmosphere in Ostrava. Review of the first screening of elements in fly dust in the Ostrava atmosphere in 1995. Hygiena. 1998;43(3):147-53. (In Czech.)

18. Ostrava agglomeration / Karvina / Frydek-Mistek [Internet]. Prague: Czech Hydrometeorological Institute; 2014 [cited 2015 Feb 2]. Available from: http://portal.chmi.cz/files/portal/docs/uoco/isko/grafroc/13groc/ gr13cz/V3_OKFM_CZ.html.

19. Jiř́k V, Volf J, Burdová J, Dluhošová Z, Mikeš P. The atmosphere in Ostrava. Monitoring of gaseous noxious substances and polycyclic aromatic hydrocarbons in the Ostrava atmosphere. Hygiena. 1998;43(1):8-18. (In Czech.)

20. Čížková H. Project Silesia. Practical application of methods of risk assessment and management. Ochr Ovzduší. 1998;10(2):4-6. (In Czech.)
21. Cernikovský L. Thirty-day trial monitoring air pollution in Ostrava. Ochr Ovzduší. 1998;10(2):9. (In Czech.)

22. Černikovský L. Air quality management - demonstration subproject of Project Silesia. Ochr Ovzduší. 1998;10(2):7-8. (In Czech.)

23. Houthuijs D, Breugelmans O, Hoek G, Vaskövi É, Miháliková E, Pastusz$\mathrm{ka} \mathrm{J}$, et al. PM10 and PM2.5 concentrations in Central and Eastern Europe: results from the Cesar study. Atmos Environ. 2001 May;35(15):2757-71.

24. Svecova V, Topinka J, Solansky I, Sram RJ. Personal exposure to volatile organic compounds in the Czech Republic. J Expo Sci Environ Epidemiol. 2012 Sep;22(5):455-60.

25. Svecova V, Topinka J, Solansky I, Rossner P Jr, Sram RJ. Personal exposure to carcinogenic polycyclic aromatic hydrocarbons in the Czech Republic. J Expo Sci Environ Epidemiol. 2013 Jul;23(4):350-5.

26. Ostro B. Outdoor air pollution. Assessing the environmental burden of diseases in national and local levels. Geneva: World Health Organization; 2004

27. World Health Organization. Health risks of air pollution in Europe HRAPIE project. Recommendations for concentration-response functions for cost-benefit analysis of particulate matter, ozone and nitrogen dioxide. Copenhagen: WHO Regional Office for Europe; 2013.

28. World Health Organization. Review of evidence on health aspects of air pollution. REVIHAAP project: technical report. Copenhagen: WHO Regional Office for Europe; 2013.

29. United States Environmental Protection Agency [Internet]. Washington, DC: EPA; 2015 [cited 2015 Apr 2]. Integrated Risk Information System (IRIS). Available from: http://cfpub.epa.gov/ncea/iris2/atoz.cfm.

30. Directive 2008/50/EC of the European Parliament and of the Council of 21 May 2008 on ambient air quality and cleaner air for Europe. Off J Eur Union. 2008 Jun 11;51(L152):1-44.

Received August 28, 2015 Accepted in revised form April 27, 2016 